\title{
SEASONAL FLOW CHARACTERISTICS IN THE APUSENI MOUNTAINS
}

\author{
G. PANDI ${ }^{1}$, Melinda VIGH ${ }^{2}$, Cs. HORVATH ${ }^{1}$
}

\begin{abstract}
Seasonal flow characteristics in the Apuseni Mountains. The geographical position and variety of Apuseni Mountains' landscape determine a very uneven distribution of rainfall, respectively river flow. It is reflected in the seasonal flow distribution through differences between the mountainous areas belonging to the four cardinal points. Flow evolution is analyzed at 16 hydrometric stations. Relations $\mathrm{q}=\mathrm{f}$ (Hmed) indicate obvious territorial differences, both quantitatively and in terms of growth rates at high altitudes. Percentage flow between areas analyzed indicates evident uniformity. Relations between the quantities of drained water highlight the bigger differences between north-south than between east-west.
\end{abstract}

Keywords: Western circulation, seasonal flow, altitude, correlation, percentage flow, flow rate

\section{FLOW'S GENETIC FACTORS}

Apuseni Mountains are characterized by a strong geological complexity, which is well reflected in the physical landscape. Mountain alignments have different directions, allowing or obstructing the dominant western air masses movement. Depression areas of different sizes are developed between the mountains, some forming true transverse corridors. Others are small, representing numerous expansions in the mountain valleys that litters the area.

Although the altitudes are not very high, they influence air movement toward the Transylvanian Depression, cloudiness variation, consequentially the rainfall quantity and distribution. The western circulation is directed mainly to the north-south barrier, giving an upward movement to wet air masses.

Eastern mountains end relatively suddenly towards Someșul Mic and Mureș corridors. There are valley corridors between peaks, which direct air moving eastward. These features influence the water flow genesis in this part of the Apuseni Mountains as air masses crossing the highest peaks receive a downward movement component.

By their position, between the Pannonian Basin and Transylvania Depression, the Apuseni Mountains are an orographic barrier to the movement of predominantly western air masses (Șerban, 2007). Along with this main regulation of flow genesis, other spatial differentiations can be identified, which are due to

1 Babes-Bolyai University, Faculty of Geography, Cluj-Napoca, Romania, email: pandi@geografie.ubbcluj.ro, hcsaba@gmail.com

${ }^{2}$ Babes-Bolyai University, Faculty of Environmental Science and Engineering, Cluj-Napoca, Romania, email: vmelindap@yahoo.com 
local conditions of precipitation and flow formation (Ujvári, 1972, Horváth, 2008). It is worth mentioning the phenomenon of foehn on the eastern slopes, with a major peak between April to June and a second maximum in October-November (Pandi, Moldovan, Vigh, 2016).

The precipitations are more intensive (over $1200 \mathrm{~mm}$ ) on the slopes exposed to the west and in mountains Vlădeasa, Bihor, Gilău. In the east and south they are significantly reduced $(800-1000 \mathrm{~mm})$. The seasonal runoff diversification is the direct result of similar variation of precipitations. The geological constitution is heterogeneous but it no influence the runoff values. The entire area is covered with forests and mountain pastures and their influence on seasonal flow is insignificant.

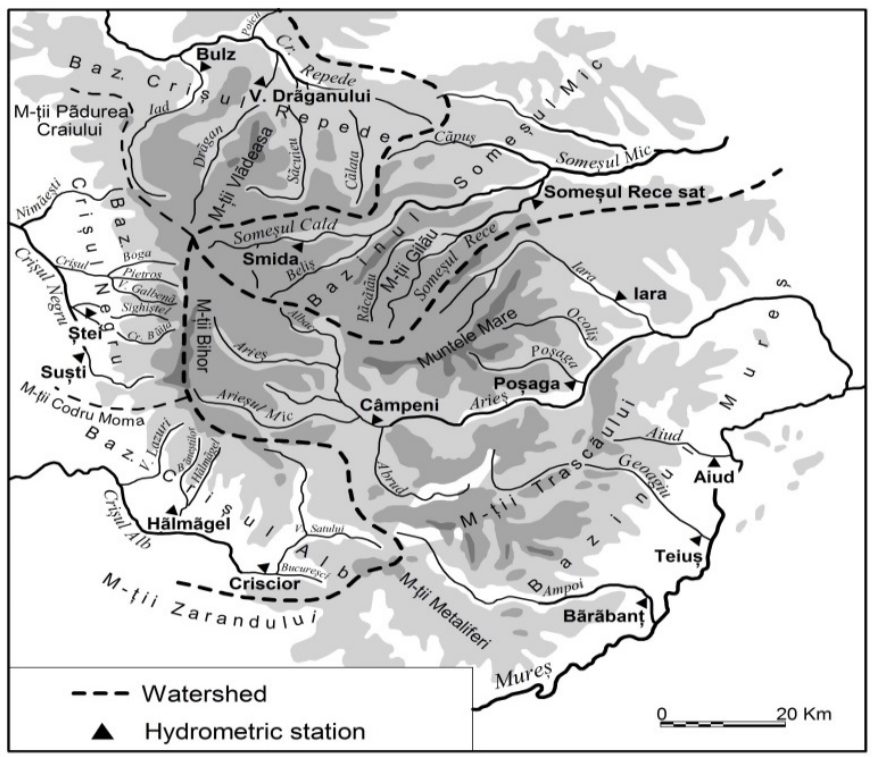

Fig. 1. The hydrographic network and hydrometric stations in the Apuseni Mountains

\section{DATA BASE AND METHOD}

Flow monitoring is organized by size and exposure of watersheds, by the richness and importance of the water resources. Of the 49 hydrometric stations, 14 were selected so as to be representative for seasonal flow characteristics. They control water basins with relatively small areas, with differentiated average altitudes, with diversified exposure, covering the entire mountain area. Six of them belong to the three Cris river basins, with predominantly western exposure, and eight on Someș and Mureș river basins, in the eastern part.

For each hydrometric station was calculated the annual average flow value of specific seasonal flow for the period 1950-1994. There has not been chosen a more recent period because in the year 1995 were suppressed several stations in the 
mountain area, which would have led to a string in data heterogeneity. With these values were drawn functions $\mathrm{q}=\mathrm{f}(\mathrm{Hm})$ for four seasons.

Table 1. Morphometric elements at stations

\begin{tabular}{|l|l|c|c|}
\hline \multicolumn{1}{|c|}{ River } & \multicolumn{1}{c|}{$\begin{array}{c}\text { Hydrometric } \\
\text { station }\end{array}$} & A (km²) & Hmed (m) \\
\hline Dragan & V. Draganului & 228 & 1161 \\
\hline Iad & Bulz & 220 & 838 \\
\hline Crisul Negru & Susti & 137 & 617 \\
\hline Crisul Baita & Stei & 65 & 796 \\
\hline Crisul Alb & Criscior & 333 & 620 \\
\hline Halmagel & Halmagel & 67 & 747 \\
\hline Somesul Cald & Smida & 103 & 1295 \\
\hline Somesul Rece & Somesul Rece sat & 328 & 1223 \\
\hline Aries & Campeni & 637 & 1020 \\
\hline Iara & Iara & 273 & 1120 \\
\hline Posaga & Posaga & 106 & 1096 \\
\hline Ampoi & Barabant & 556 & 716 \\
\hline Geoagiu & Teius & 185 & 851 \\
\hline Aiud & Aiud & 180 & 632 \\
\hline
\end{tabular}

Because there was observed a flow differentiation both on west to east and on north to south directions, were calculated percentage flow values for each season.

To illustrate the more obvious differences of seasonal runoff were calculated relations between total water flow values in west, respectively in east, and the flow ratio from the west and east. With the same reasoning, flow differentiation was analyzed between north and south.

\section{RESULTS}

Correlations of specific flow with the average altitude of watersheds apart in all seasons, the flow towards the four cardinal points. In each graph can be drawn clear correlations for western and eastern basins, respectively northern and southern mountain area.

\subsection{West-East differentiation of seasonal flow}

In spring, the correlation for western stations is closer than those in the east. Flow differences between the west and east are at maximum. They decrease slightly toward higher altitudes. At $1000 \mathrm{~m}$ west, flow value is of $42 \mathrm{l} / \mathrm{s} \cdot \mathrm{km}^{2}$, and in east it is of just $22 \mathrm{l} / \mathrm{s} . \mathrm{km}^{2}$.

In summer appears the tightest correlations observed on both sides of the Apuseni Mountains. The trend of variation with altitude is reverse than in spring. At higher altitudes differences are increasing. At $1000 \mathrm{~m}$ in the western basins are drained $26 \mathrm{l} / \mathrm{s} . \mathrm{km}^{2}$, and in east this value is of $14 \mathrm{l} / \mathrm{s} . \mathrm{km}^{2}$. 


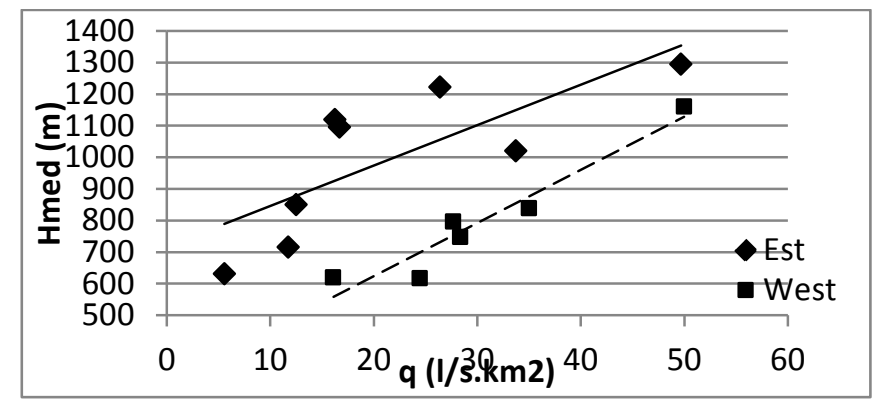

Fig. 2. West-east differentiation of spring flow

In autumn, the correlations allure resembles the one in spring. Here also appears differences increasing trend at high altitudes. Thus at $1000 \mathrm{~m}$ were achieved values of $17 \mathrm{l} / \mathrm{s} \cdot \mathrm{km}^{2}$ in the west, and in the east $8 \mathrm{l} / \mathrm{s} \cdot \mathrm{km}^{2}$, which shows a decrease compared to the summer.

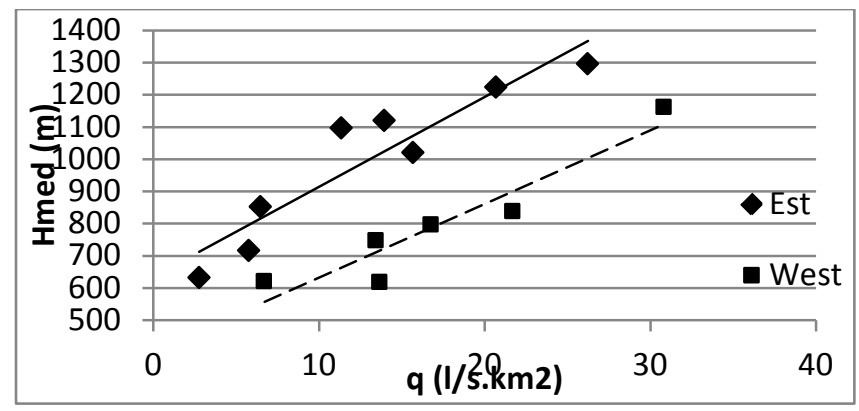

Fig. 3. West-east differentiation of summer flow

Winter correlations are the weakest, due to different water quantities retention in ice formations (Sorocovschi at all, 2015). For example, the water flow in V. Drăganului is very small, and at stations Aiud, Bărăbanţ and Câmpeni is too high. Differences between the two trends are higher than in summer and autumn. At $900 \mathrm{~m}$ altitude there are $22 \mathrm{l} / \mathrm{s} \cdot \mathrm{km}^{2}$ in west and $6 \mathrm{l} / \mathrm{s} . \mathrm{km}^{2}$ in east.

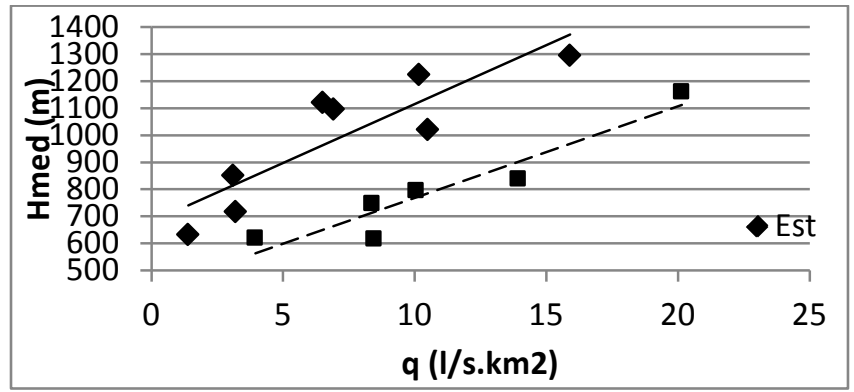

Fig. 4. West-east differentiation of autumn flow 
Analyzing percentage water flow for the two sides of the Apuseni Mountains emerges an interesting conclusion. Distribution of the seasons is very similar to the western and eastern slopes. In spring, the percentage is almost identical: $39 \%$ in the west and $40 \%$ in the east. The summer and autumn slow percentage in west is slightly higher, and in winter the runoff is richer by two percent in the east.

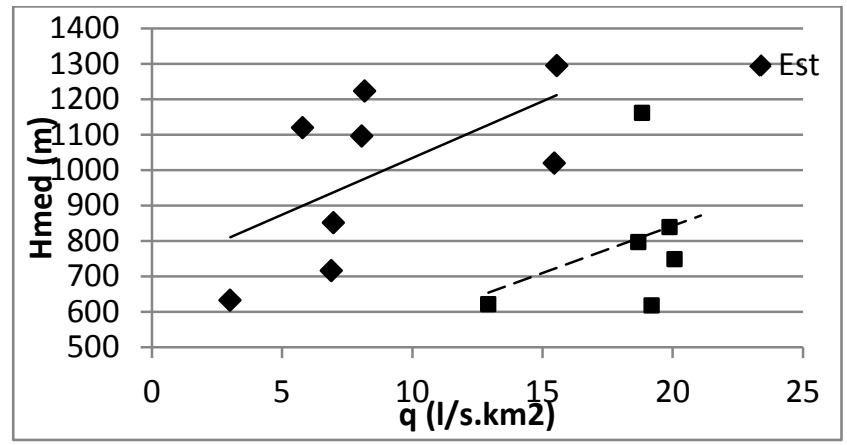

Fig. 5. West-east differentiation of winter flow

Flow ratio reflects clear distinction between west and east. The ratio between western flow and total flow is always an improper fraction. The values are close to those in the first three seasons (1.14 - 1.20), and increase to 1.35 in winter. Relationship between eastern and total flow is as proper fraction, with similar values from spring to autumn: $0.80-0.86$. In winter, the decrease is higher, at to 0.65 . The ratio between western and eastern flow is greatest in winter (2.09) and the lowest in summer (1.34).
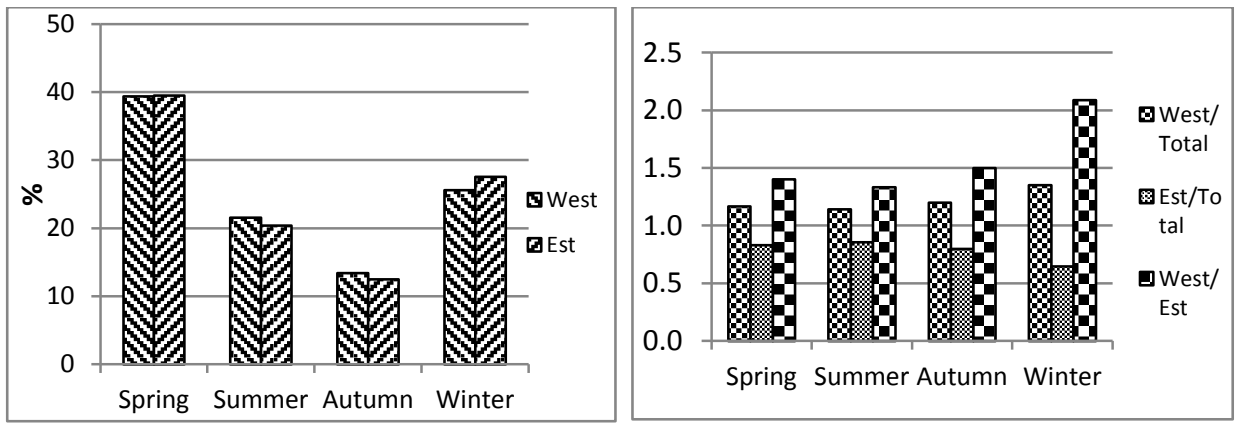

Fig. 6. Percentage water flow and flow ratios between west and east

\subsection{North-south differentiation of seasonal flow}

The correlations between specific seasonal flow and average altitude of river basins are scattered. The differences between the northern and southern flow 
are lower than east-west relations. Hălmăgel hydrometric station was not used because every season is not align with the other stations in the south.

In spring, southern points presents an ordering more pronounced than those in the north. Exceptions are the values at Someș Rece sat, which is very small, and from Câmpeni and Crişcior that are too high. The two trends indicate almost equal increasing rates, and are closer than the east-west relationship. The amount of water flow to $1000 \mathrm{~m}$ is $37 \mathrm{l} / \mathrm{s} \cdot \mathrm{km}^{2}$ and $27 \mathrm{l} / \mathrm{s} \cdot \mathrm{km}^{2}$ in south.

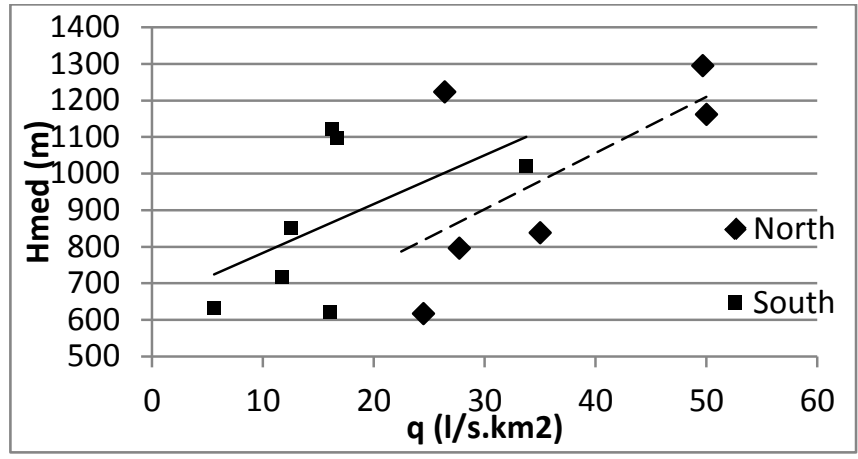

Fig. 7. North-south differentiation of spring flow

Summer relations points show clear trends but are more scattered at high altitudes. Correlation lines departs slightly toward higher altitudes, as in east-west relations. At $1000 \mathrm{~m}$, water flow values reach $22 \mathrm{l} / \mathrm{s} \cdot \mathrm{km}^{2}$ in north and $12 \mathrm{l} / \mathrm{s} \cdot \mathrm{km}^{2}$ in south.

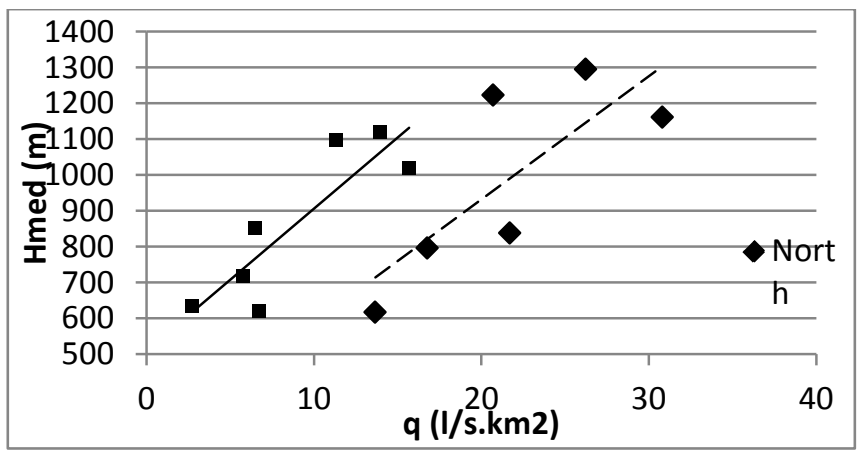

Fig. 8. North-south differentiation of summer flow

During autumn, southern stations show a more consistent trend. The Someșul Rece sat hydrometric station has a very low value. Because of this, the northern correlation line indicates an increasing rate that is too high. Over $1000 \mathrm{~m}$, the flow in the north is $13 \mathrm{l} / \mathrm{s} . \mathrm{km}^{2}$ and south $7 \mathrm{l} / \mathrm{s} . \mathrm{km}^{2}$.

Winter points, both in the North and the South, does not show clear trends. Their scattering is so great that there was not possible to draw straight correlation lines to indicate regularities in variation. In the north, the points are almost vertical, 
and at Someșul Rece sat the value is very small. In south, the Câmpeni and Crişcior stations distinguish by very high values. The cause of this situation is differentiated water river flow influencing by winter phenomena.

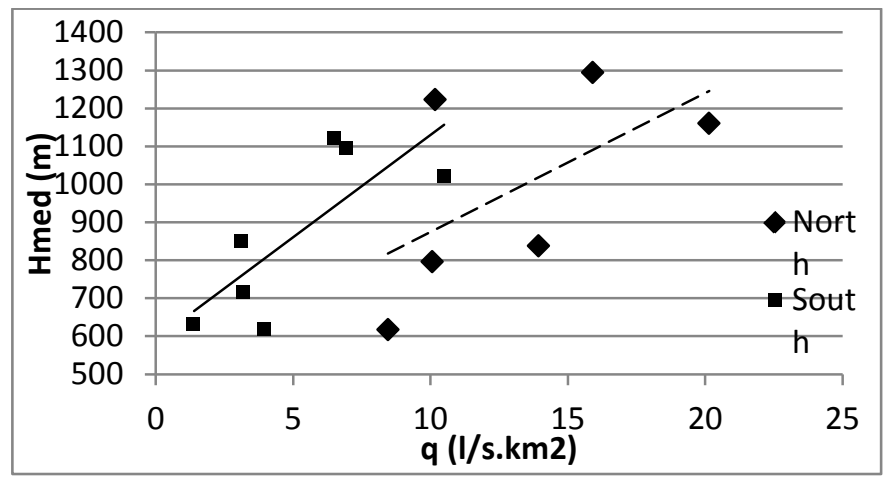

Fig. 9. North-south differentiation of autumn flow

The northern percentage flow in higher in spring and winter, with $2 \%$ and $3 \%$. Size differences of flow percentage is $2 \%$ in summer and autumn, in favor of the south. Flow ratio indicate very clear differences between north and south. Even more highlighted than between west and east.

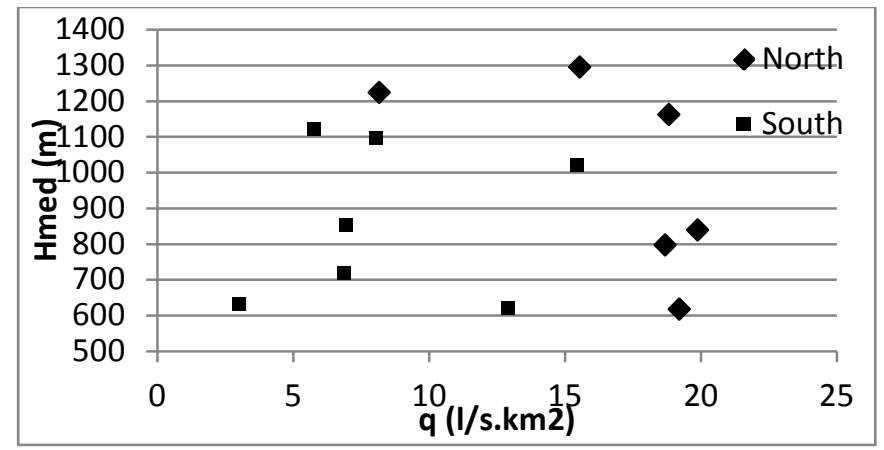

Fig. 10. North-South differentiation of winter flow

The value of flow ratio between northern and total flow varies little, between 1.44 in autumn and 1.33 in winter. The ratio between south and total flow differ slightly more, with a maximum in winter (0.67) and a minimum in autumn (0.56). Differences between north-south ratios are higher: 2.58 in autumn, respectively 1.98 in winter.

\section{CONCLUSIONS}

Apuseni Mountains landscape characteristics and position have a significant influence on the diversification of seasonal water flow. Along with 
these factors is observed the influence of air masses direction of movement and of water's retention in ice formations.
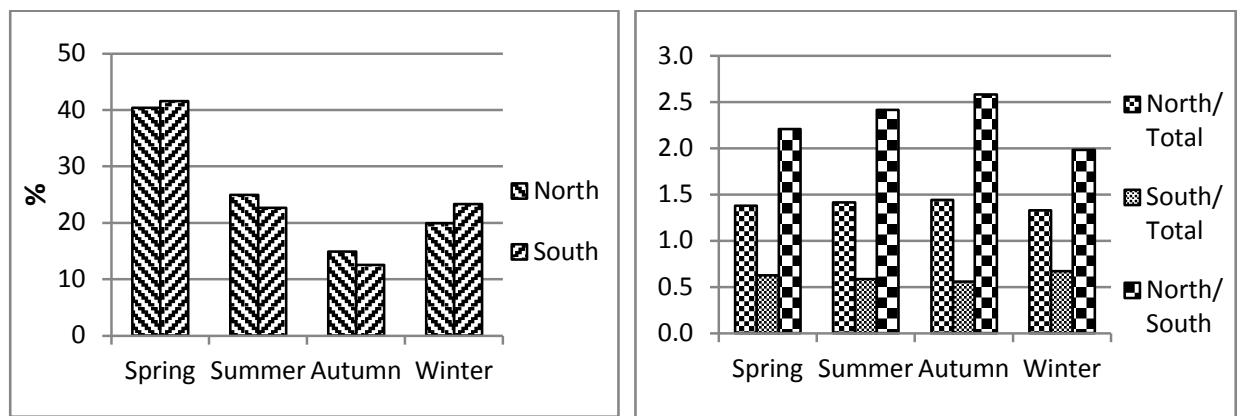

Fig. 11. Percentage flow and flow ratios between north and south

It can be observed obvious differences between the laws of specific flow between west and east, north and south respectively. Correlations with altitude generally express regularities more obvious than at seasonal flow. Local factors sometimes cause relatively large flow deviations from these regularities at some stations. The rate of runoff increase to high altitudes differ both in space and for every season.

For percentage flow, the variation laws are almost identical for all four areas analyzed. Flow ratios in different areas reveal major space differences and less seasonal discrepancies.

\section{REFERENCES}

1. Horváth Cs. (2008), Studiul lacurilor de acumulare din bazinul superior al Crișului Repede, Edit.Casa Cărții de știință, Cluj

2. Pandi G., Moldovan F., Vigh M. (2016), The influences of foehn processes on river flows from eastern Apuseni Mountains, Water Resources and Wetland, Edit.Transversal, Târgoviște

3. Sorocovschi V., Pandi G., Ungur Corina, Horváth Cs., Bătinaș R. (2015), Southwestern Apuseni Mountains small rivers seasonal hydrological flow regim, Air and water Components of the Emvironment, Edit. Presa Universitara Clujeana, Cluj

4. Șerban Gh. (2007), Lacurile de acumulare din bazinul superior al Someșului Mic - Studiu hidrogeografic, Edit.Presa Universitară Clujeană, Cluj

5. Ujvári I. (1972), Geografia apelor României, Edit. Științificăă, București 